\title{
Extracellular Calcium and Cholinergic Stimulation of Isolated Canine Parietal Cells
}

\author{
ANDREw H. SOLL, Medical and Research Services and Center for Ulcer Research and \\ Education at Veterans Administration Wadsworth Hospital Center, and \\ University of California at Los Angeles, California 90073
}

A B S T R A C T The role of calcium gating in cholinergic stimulation of the function of parietal cells was studied using cells isolated from canine fundic mucosa by treatment with collagenase and EDTA and enriched by velocity separation in an elutriator rotor. Monitoring the accumulation of $\left[{ }^{14} \mathrm{C}\right]$ aminopyrine as an index of parietal cell response, stimulation by carbachol, but not by histamine, was highly dependent upon the concentration of extracellular calcium. Incubation of parietal cells in $0.1 \mathrm{mM}$ calcium, rather than the usual 1.8-mM concentration, reduced the response to $100 \mu \mathrm{M}$ carbachol by $92 \pm 2 \%$, whereas histamine stimulation was impaired by $28 \pm 5 \%$. A similar reduction in extracellular calcium suppressed the response to gastrin $(100 \mathrm{nM})$ by $67 \pm 7 \%$. The impairment of cholinergic stimulation found at low extracellular calcium concentrations was rapidly reversed with the readdition of calcium. Lanthanum, which blocks calcium movement across membranes, caused a similar pattern of effects on secretagogue stimulation of aminopyrine accumulation, with $100 \mu \mathrm{M}$ lanthanum suppressing carbachol stimulation by $83 \pm 2 \%$. This concentration of lanthanum suppressed gastrin stimulation by $40 \pm 7 \%$ and histamine stimulation by only $12 \pm 9 \%$.

Carbachol, but not histamine nor gastrin, stimulated ${ }^{45} \mathrm{Ca}^{++}$uptake. The magnitude of carbacholstimulated calcium uptake correlated with the parietal cell content of the fractions examined $(r=0.88)$, and was dose responsive over carbachol concentrations from $1 \mu \mathrm{M}$ to $1 \mathrm{mM}$. Atropine $(100 \mathrm{nM})$ caused surmountable inhibition, and these effects of carbachol and atropine on calcium uptake correlated with their

This work was presented in part at the meetings of the American Gastroenterological Association, 21-23 May 1979, in New Orleans, La.

Dr. Soll is the recipient of Clinical Investigatorship from the Veterans Administration Wadsworth Hospital Center.

Received for publication 11 February 1980 and in revised form 23 February 1981. effects on oxygen consumption $(r=0.93)$ and $\left[{ }^{14} \mathrm{C}\right]-$ aminopyrine accumulation $(r=0.90)$. Cells preloaded with ${ }^{45} \mathrm{Ca}^{++}$lost cellular calcium in a time-dependent fashion; however, this rate of egress was not accelerated by treatment with histamine, gastrin, or carbachol, thus failing to implicate mobilization of intracellular calcium as primary mechanism for activation of parietal cell function. These data indicate a close link between stimulation of parietal cell function and enhancement of calcium influx by cholinergic agents.

\section{INTRODUCTION}

Increases in cytosol calcium couple cell activation to cell response in a variety of cell types, with chemical transmitters enhancing either the influx of extracellular calcium or the release of calcium from intracellular binding sites to produce the rises in cytosol calcium concentration (2-6). Heart and skeletal muscle exemplify these diverse sources of calcium, with activation in heart muscle involving enhanced influx of extracellular calcium and activation in skeletal muscle triggering calcium release from sarcoplasmic reticulum. With removal of extracellular calcium, contractions immediately cease in heart muscle, but continue for hours in skeletal muscle (5).

In tissues where cell activation is linked to enhanced influx of calcium, the magnitude of cell response will be dependent upon the extracellular calcium concentration $(5,7-9)$. Lanthanum provides another tool for studying the role of calcium, since low concentrations of this trivalent cation impair both calcium influx and efflux across the plasma membrane and displace surface-bound calcium (10). Lastly, stimulant effects on calcium influx can be directly tested using ${ }^{45} \mathrm{Ca}^{++}(2-4,9,11)$. Study of the role of mobilization of intracellular calcium in cell activation requires other approaches, such as monitoring the egress of ${ }^{45} \mathrm{Ca}^{++}$from preloaded cells or use of dye probes which will shift fluorescence with alteration of calcium concentrations $(2-4,6,12)$. 
In previous studies with isolated canine parietal cells, histamine, cholinergic agents, and gastrin caused cell activation as evidenced by changes such as increased oxygen consumption (13) and the accumulation of $\left[{ }^{14} \mathrm{C}\right]$ aminopyrine (14). Activation produced by histamine, but not by cholinergic agents or gastrin, was linked to increased production of cyclic AMP (15). The present work examines the role of the calcium in the parietal cell response to stimulation. The dependence of cell activation upon the concentration of extracellular calcium was assessed by monitoring the accumulation of $\left[{ }^{14} \mathrm{C}\right]$ aminopyrine $(\mathrm{AP})^{1}$ as an index of parietal cell response, a technique developed by Berglindh and co-workers in their studies with isolated rabbit gastric glands (16). AP concentrates within the tubulovesicles and secretory canaliculi of the parietal cell by $\mathrm{pH}$ partition, with the amount accumulating reflecting the quantity of acid sequestered within the parietal cell rather than the actual quantity of acid secreted (14). Additionally, the effects of lanthanum on parietal cell response to stimulation were assessed. Finally, alterations in the rate of ${ }^{45} \mathrm{Ca}^{++}$ influx and egress with cell activation by histamine, carbachol, and gastrin, alone and in combination, was measured.

\section{METHODS}

Cells were dispersed from canine fundic mucosa by sequential treatment with crude collagenase and EDTA with the parietal cells enriched to a mean content of $50 \pm 3 \%$ using a Beckman elutriator rotor (Beckman Instruments, Fullerton, Calif.) $(13,14,17)$. AP accumulation was determined on cell suspensions incubated for $20 \mathrm{~min}$ in the presence of $0.05 \mu \mathrm{Ci} / \mathrm{ml}(3 \mu \mathrm{M})$ of $\left[{ }^{14} \mathrm{C}\right]$ aminopyrine, after which triplicate samples of each suspension were sedimented and the radioactivity in the cell pellet determined (14). The quantity of accumulated AP was expressed as the AP accumulation ratio, the ratio of the AP concentration in the parietal cells to that in the medium (14). With the exception of the prolonged ${ }^{45} \mathrm{Ca}^{++}$uptake studies and the studies with lanthanum, the AP experiments were done using Earles' balanced salt solution (purchased from Gibco Laboratories, Grand Island, N. Y., without $\mathrm{Ca}^{++}$or $\left.\mathrm{Mg}^{++}\right)$. Hepes $(10 \mathrm{mM})$ and $0.1 \%$

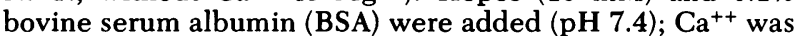
present in the concentrations indicated in the figure legends, and $\mathrm{Mg}^{++}$was present at $0.8 \mathrm{mM}$, unless otherwise noted. For studies in which the calcium concentration was varied, cells were washed twice in the medium to be used. The AP incubation was started within $20 \mathrm{~min}$ of this final resuspension. The studies with lanthanum were done in a buffer formulated without $\mathrm{PO}_{4}, \mathrm{SO}_{4}$, or $\mathrm{HCO}_{3}(10)$, so as to avoid precipitation of the lanthanum (in $\mathrm{mM}, \mathrm{NaCl}, 133 ; \mathrm{KCl}, 3.6$; $\mathrm{CaCl}_{2}, 1.8 ; \mathrm{MgCl}, 0.3$; glucose 16.0 , and Hepes, 10). These methods and the materials used have been reported in detail in the indicated references. As in the previous studies (14), occasional preparations of canine parietal cells showed no AP accumulation in response to stimulation (less than two- to

${ }^{1}$ Abbreviations used in this manuscript: AP, ${ }^{14} \mathrm{C}$-aminopyrine; BSA, bovine serum albumin. threefold increase over basal); 7 of 41 preparations were dropped using this critera.

${ }^{45} \mathrm{Ca}^{++}$uptake was studied on cells suspended in Earles' buffer with $1.8 \mathrm{mM} \mathrm{Ca}^{++}$and $0.8 \mathrm{mM} \mathrm{Mg}^{++}$. After an initial $10 \mathrm{~min}$ incubation at $37^{\circ} \mathrm{C}, 0.5 \mu \mathrm{Ci} / \mathrm{ml}$ of ${ }^{45} \mathrm{Ca}^{++}(0.5 \mu \mathrm{M})$ and the indicated stimulants were added. Triplicate $0.5 \mathrm{ml}$ samples of each cell suspension were layered over $0.75 \mathrm{ml}$ of $12 \% \mathrm{BSA}$ in $80 \%$ Hanks' salt solution in $1.5-\mathrm{ml}$ microfuge tubes and centrifuged for $1 \mathrm{~min}$ at $8,700 \mathrm{~g}$. The supernate was aspirated, $1 \mathrm{ml}$ of Hanks' solution ( $0.1 \% \mathrm{BSA})$ was added without resuspension of the pellet, and the tubes were centrifuged again for $1 \mathrm{~min}$. After aspirating, the tips were excised and submerged overnight under $0.5 \mathrm{ml}$ of either tissue solubilizer (NCS, Amersham Corp., Evanston, Ill.) or water. ACS (8 ml) was then added and the radioactivity determined in a LKB scintillation counter (LKB Instruments, Inc., Rockville, Md.). The quantity of ${ }^{45} \mathrm{Ca}^{++}$present in the trapped extracellular volume in the cell pellet was estimated from the proportion of $\left[{ }^{14} \mathrm{C}\right]$ mannitol retained by similar cell pellets or by adding 5 mM EDTA to cell suspensions followed by addition of ${ }^{45} \mathrm{Ca}^{++}$. The counts trapped in the presence of EDTA were $\sim 150$ cpm for a cell pellet with $1.5 \times 10^{6}$ cells, and these counts were subtracted. These latter counts represented $<10 \%$ of ${ }^{45} \mathrm{Ca}^{++}$accumulated in the presence of carbachol $(100$ $\mu \mathrm{M})$ at $10 \mathrm{~min}$ in most experiments. Data were expressed in nanomoles of calcium taken up per $10^{6}$ cells. ${ }^{45} \mathrm{Ca}^{++}(24.1$ $\mu \mathrm{Ci} / \mu \mathrm{g}$ ) was purchased from New England Nuclear, Boston, Mass. Total cellular calcium determined on sonicated cell pellets using a Perkin-Elmer flame photometer (Perkin-Elmer Corp., Norwalk, Conn.) was $18 \pm 3 \mathrm{nmol} / 10^{6}$ cells $(n=3)$, with correction for trapped medium made on the basis of the $\left[{ }^{3} \mathbf{H}\right]$ mannitol content of the pellets.

The mean of the triplicate samples from one or two cell suspensions was calculated and used for Student's $t$ test analyses, with $n$ equal to the number of cell preparations. Standard errors are depicted in the figures and given following the \pm signs in the text, table, and figure legends. For the cell separation experiments, correlation coefficients were calculated using simple linear regression analyses and combined using the Fisher " $z$ " transformation (18).

\section{RESULTS}

The effects of the extracellular calcium concentration on AP accumulation. Cholinergic-stimulated AP accumulation was markedly dependent upon the extracellular calcium concentration. The response to $100 \mu \mathrm{M}$ carbachol in $0.1 \mathrm{mM}$ calcium was $7.9 \pm 1.6 \%$ ( $n=15, P<0.005$ ) of that found in $1.8 \mathrm{mM}$ calcium (Fig. 1B). The response to carbachol showed a high degree of dependence on the calcium concentration in the medium, as evidenced by the steep slope $(50.2 \pm 1.8)$ and correlation coefficient of $0.90(P<0.005)$ found in the linear regression analysis. ${ }^{2}$ The impairment of

\footnotetext{
${ }^{2}$ Correlations between the effects of stimulants on AP accumulation and extracellular calcium concentration were done on the data from the 10 cell preparations graphed in Fig. 1. AP accumulation was normalized as the percentage of response found for that treatment group in $1.8 \mathrm{mM}$ calcium The data were then fit by simple linear regression analysis to the expression $y=a+b x$. The correlation coefficient for the relationship was derived from the data for the separate cell preparations using the Fisher " $z$ " transformation (18).
} 


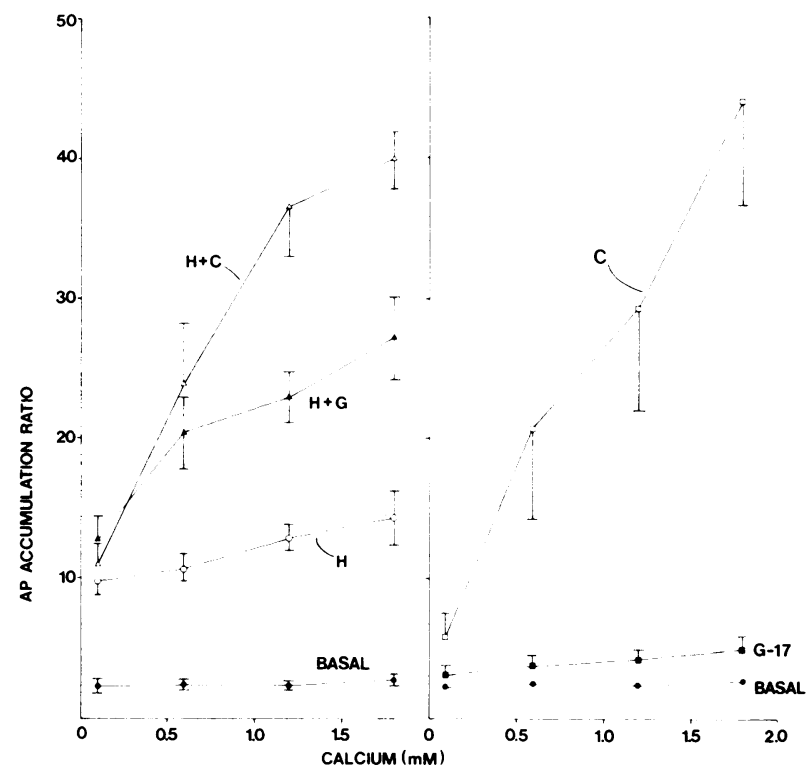

Figure 1 The effect of $\mathrm{Ca}^{++}$concentration on AP accumulation. AP accumulation was determined at four concentrations of calcium $(0.1,0.6,1.2$, and $1.8 \mathrm{mM})$ for unstimulated cells (basal) and cells stimulated by $10 \mu . \mathrm{M}$ histamine $(\mathrm{H}), 100 \mathrm{nM}$ gastrin (G), $100 \mu \mathrm{M}$ carbachol (C), $10 \mu \mathrm{M}$ histamine plus 100 $\mathrm{nM}$ gastrin, and $10 \mu \mathrm{M}$ histamine plus $1 \mu \mathrm{M}$ carbachol. Magnesium was present at $0.8 \mathrm{mM}$, and cells were studied after a 20 -min incubation. Data are the mean $\pm \mathrm{SE}$ from 10 preparations of cells, with the exception of histamine plus carbachol, which are the mean from five preparations.

carbachol stimulation by a lowered extracellular calcium concentrations was not reversed with carbachol concentrations up to $1 \mathrm{mM}$ (Fig. 2). In contrast, the response to histamine was minimally suppressed by removal of extracellular calcium; the response to 10 $\mu \mathrm{M}$ histamine in $0.1 \mathrm{mM}$ calcium was $72.3 \pm 4.6 \%$ ( $n=15, P<0.05$ ) of that found in $1.8 \mathrm{mM}$ calcium (Fig. 1A). Reflecting this minimal dependency upon extracellular calcium, the slope for the linear regression line relating histamine-stimulated AP accumulation and the calcium concentration was shallow $(18.6 \pm 5.0)$ and of borderline statistical significance $(r=0.70, P=0.05) .{ }^{2}$ Only a small change was found in the dose response relation for histamine at different calcium concentrations (Fig. 2). Corresponding to the marked effect of calcium removal on cholinergic stimulation, the potentiated response to the combination of histamine and carbachol was markedly impaired at low calcium concentrations, with the response to the combination in $0.1 \mathrm{mM}$ calcium equivalent to that found with histamine alone (Fig. 1A).

The small response to gastrin was also impaired at low calcium concentrations, with gastrin stimulation in $0.1 \mathrm{mM}$ calcium $32.8 \pm 7.3 \%(n=12, P<0.01)$ of that found in $1.8 \mathrm{mM}$ calcium (Fig. 1B). The slope

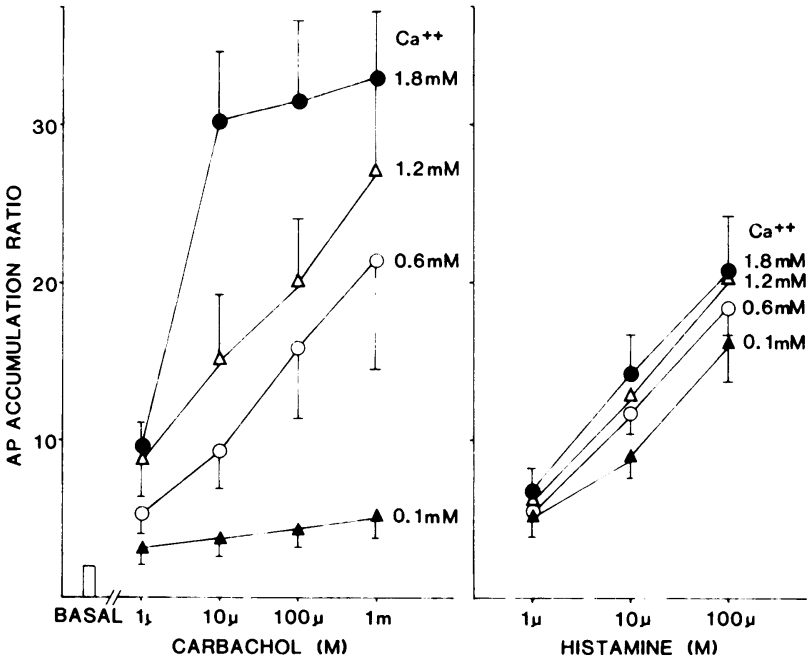

Figure 2 Dose-response relations for carbachol and histamine stimulation of AP accumulation in variable calcium concentrations. Dose-response relationships are the mean of data from eight of the preparations described in the legend to Fig. 1.

for the line relating gastrin-stimulated AP accumulation and extracellular calcium concentration was intermediate between that found for carbachol and for histamine $(34.3 \pm 7.3, r=0.88, P<0.05) .^{2}$ Reflecting this moderate dependency of gastrin responsiveness upon extracellular calcium, the potentiated response to histamine and gastrin was also impaired at low calcium concentrations (Fig. 1A).

Basal uptake of AP was not altered by concentrations of calcium from 0.1 to $5.0 \mathrm{mM}$, as long as the magnesium concentration was held constant (Fig. 1, Table I). When the calcium concentration was 1.8 or $5.0 \mathrm{mM}$, the removal of magnesium produced an increase in basal AP accumulation (Table I). In contrast, basal AP accumulation was suppressed when the magnesium concentration was increased to $5.0 \mathrm{mM}$ (Table I).

The impairment of the carbachol-stimulated AP accumulation at low calcium concentrations was rapidly reversible with restoration of extra-cellular calcium concentration. For these studies, cells were incubated for an initial 20-min period in a calcium concentration of either 0.1 or $1.8 \mathrm{mM}$. After this initial period, carbachol and AP were simultaneously added and the calcium restored to a concentration of $1.8 \mathrm{mM}$ in one of two groups initially in $0.1 \mathrm{mM}$ calcium. The accumulation of AP was measured over the next $20 \mathrm{~min}$. Cells that remained in low calcium had the expected impaired response to carbachol (Fig. 3). When the calcium was restored to normal following an initial incubation in low calcium, the time course for carbachol-stimulated AP accumulation was similar to that 
TABLE I

Effects of Calcium and Magnesium on Basal AP Accumulation

\begin{tabular}{lccccc}
\hline \multicolumn{5}{c}{ Concentrations of calcium and magnesium during incubation } \\
\hline$\left[\mathrm{Ca}^{++}\right], m M$ & 1.8 & 5.0 & 1.8 & 5.0 & 1.8 \\
{$\left[\mathrm{Mg}^{++}\right], m M$} & 1.2 & 1.2 & 0 & 0 & 5.0 \\
\hline \multicolumn{1}{c}{ Treatment } & \multicolumn{5}{c}{ AP accumulation ratios } \\
\hline Basal* & $2.2 \pm 0.5$ & $1.8 \pm 0.5$ & $6.0 \pm 2.0$ & $8.9 \pm 3.5 \ddagger$ & $1.4 \pm 0.1 \ddagger$ \\
Carbachol*, $10 \mu \mathrm{M}$ & $33.0 \pm 11.9$ & $25.8 \pm 8.8$ & $45.3 \pm 15.0$ & $24.0 \pm 10.5$ & $24.9 \pm 14.7$ \\
Histamine* $10 \mu \mathrm{M}$ & $8.5 \pm 1.8$ & $7.0 \pm 1.4$ & $20.5 \pm 6.2$ & $19.5 \pm 6.2$ & $6.8 \pm 2.2$ \\
\hline
\end{tabular}

* Cells were incubated in Earles' solution at the $\mathrm{Ca}^{++}$and $\mathrm{Mg}^{++}$concentrations indicated in the first two rows for a 20 -min period, during which AP accumulation was determined as described in Methods. The AP ratios, from six separate preparations, for untreated cells and for cells treated with carbachol and histamine are indicated in the columns under the concentrations of $\mathrm{Mg}^{++}$and $\mathrm{Ca}^{++}$present during the incubations. The counts trapped in the presence of $0.1 \mathrm{mM}$ dinitrophenol were subtracted.

$\$$ Statistical significance of the difference by paired $t$ test $(P<0.05)$ from cells incubated in $1.8 \mathrm{mM} \mathrm{Ca}^{++}$and $1.2 \mathrm{mM} \mathrm{Mg}^{++}$.

found for the cells incubated only in normal calcium (Fig. 3).

The effects of lanthanum on stimulated AP accumulation. In the presence of $100 \mu \mathrm{M}$ lanthanum, the response to $10 \mu \mathrm{M}$ carbachol was impaired by $83.4 \pm 1.5 \%$ ( $n=8, P<0.005)$, whereas the response to $10 \mu \mathrm{M}$ histamine was reduced by only $12.0 \pm 8.8 \%$ $(n=8,0.05<P<0.1)$ (Fig. 4). Lanthanum inhibition of carbachol was not surmounted at concentrations of carbachol up to $1 \mathrm{mM}$ (Fig. 4). Concentrations of lanthanum between $0.1 \mu \mathrm{M}$ and $1 \mathrm{mM}$ inhibited the response to $100 \mu \mathrm{M}$ carbachol, with $50 \%$ inhibition found with a lanthanum concentration of about $1 \mu \mathrm{M}$

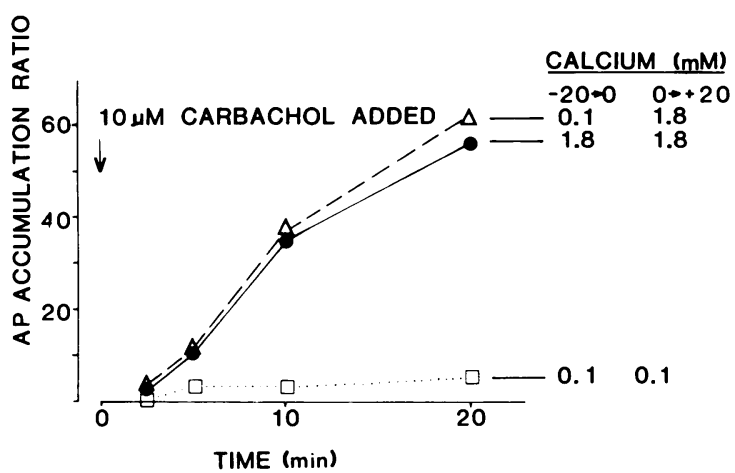

FIGURE 3 The reversibility of the effects of calcium removal on the response to carbachol. Cells were incubated for an initial 20 -min period $(-20 \rightarrow 0 \mathrm{~min})$ in either 0.1 or $1.8 \mathrm{mM}$ calcium, as indicated. Carbachol was added to each of the three groups at zero time, and the calcium concentration was increased to $1.8 \mathrm{mM}$ in one of the groups initially incubated in $0.1 \mathrm{mM}$ calcium. AP accumulation was then determined at the indicated times. The data are from a single preparation; similar findings were also obtained with two other preparations of cells.
(Fig. 5). Lanthanum $(100 \mu \mathrm{M})$ caused a $40.6 \pm 6.5 \%$ $(n=8), P<0.05)$ impairment of the response to 100 $\mathrm{nM}$ gastrin and a $47.7 \pm 6.0 \%(n=8, P=0.01)$ impairment of the response to $10 \mathrm{nM}$ gastrin (Fig. 4).

${ }^{45} \mathrm{Ca}^{++}$uptake. Carbachol significantly increased ${ }^{45} \mathrm{Ca}^{++}$uptake by parietal cell enriched fractions (Fig. 6A). An enhanced accumulation of calcium was also evident after pelleting the cells through an albumin solution with $5 \mathrm{mM}$ EDTA added to strip off the rapidly exchangeable calcium (Fig. 7). Cholinergic
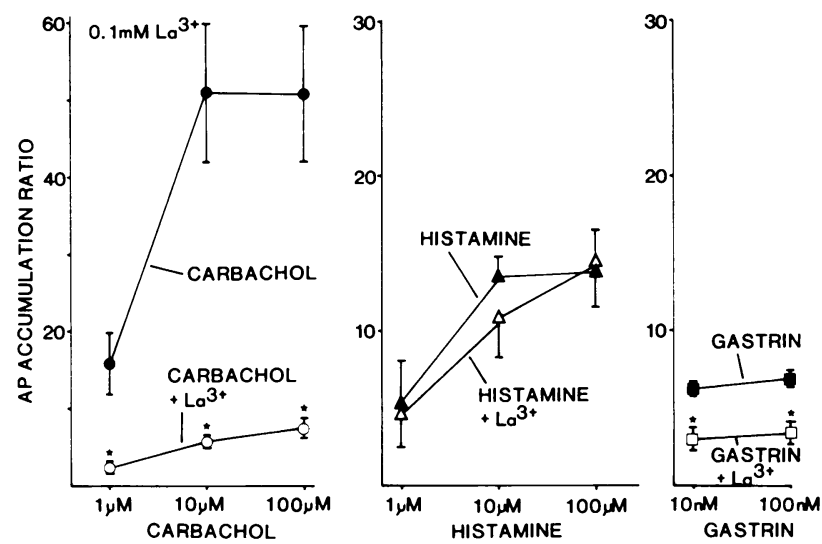

FIgURE 4 The effect of lanthanum on secretagogue-stimulated AP accumulation. On panels A, B, and C respectively the dose-response relationships for carbachol, histamine, and gastrin are shown with and without the addition of 100 $\mu \mathrm{M}$ lanthanum $\left(\mathrm{La}^{3+}\right)$. The data, expressed as the AP accumulation ratio minus basal, are the mean $\pm S E$ for four preparations of cells. The statistical significance $(P<0.01)$ of the difference between the groups treated and not treated with lanthanum is indicated by the stars. Medium composition for these studies was noted in Methods. An incubation of $20 \mathrm{~min}$ was used. 


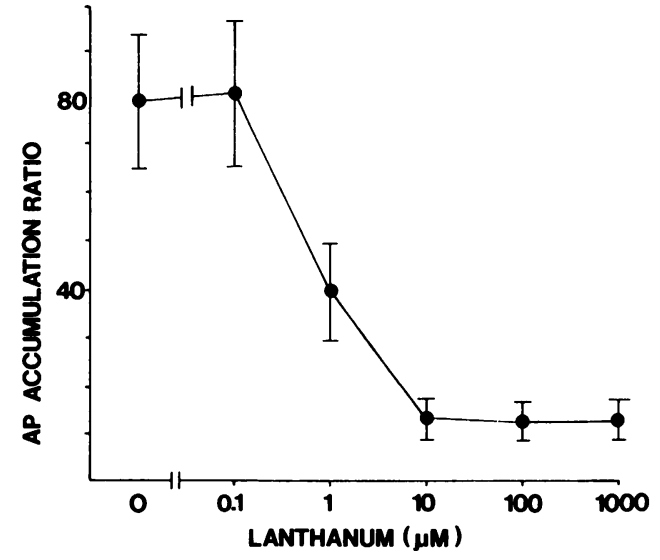

FIGURE 5 The effects of various concentrations of lanthanum on AP accumulation stimulated by $100 \mu \mathrm{M}$ carbachol. The data are from four separate preparations of cells and are expressed as the AP accumulation ratio minus basal.

enhancement of the rate of ${ }^{45} \mathrm{Ca}^{++}$uptake was evident over the first $30 \mathrm{~min}$ of incubation, with the rate of increase of the cell content of ${ }^{45} \mathrm{Ca}^{++}$during more prolonged incubation not different from that found with untreated cells (Fig. 7). During this 3-h period, 10-20\% of the cellular calcium was exchanged (based upon an estimate of $18 \mathrm{nmol}$ of total calcium $/ 10^{6}$ cells); however the cells did not reach a steady-state level of ${ }^{45} \mathrm{Ca}^{++}$accumulation during this period (Fig. 7). Carbachol stimulation of calcium uptake was dose dependent over a concentration range of carbachol from $1 \mu \mathrm{M}$ to $1 \mathrm{mM}$ (Fig. 8). Atropine (100 $\mathrm{nM}$ ) produced a right-ward shift of the dose-response relationship for carbachol (Fig. 8). Carbachol stimulation of calcium uptake correlated with its effects on oxygen con-

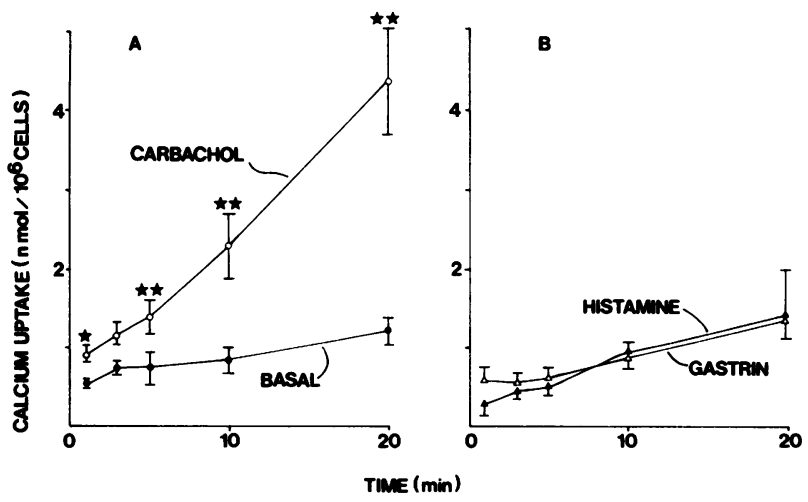

Figure 6 The effects of stimulants on ${ }^{45} \mathrm{Ca}^{++}$uptake into parietal cells. Parietal cells were incubated for the indicated times in the presence of $0.5 \mu \mathrm{Ci} / \mathrm{ml}^{45} \mathrm{Ca}^{++}$plus carbachol $(100 \mu \mathrm{M})$, histamine $(10 \mu \mathrm{M})$, or gastrin $(100 \mathrm{nM})$ as noted. The data are the mean from four preparations of cells. Statistical significance of the difference from basal influx is indicated. Cells were studied in Earles' balanced salt solution (1.8 $\mathrm{mM} \mathrm{Ca}{ }^{++}, 0.8 \mathrm{mM} \mathrm{Mg}$ ).

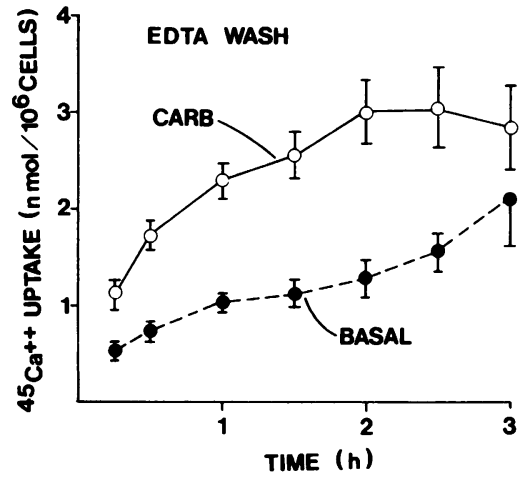

FigUre $7{ }^{45} \mathrm{Ca}^{++}$uptake during prolonged incubation. Parietal cell enriched fractions were incubated for up to $3 \mathrm{~h}$ in minimum essential medium $\left(1.8 \mathrm{mM} \mathrm{Ca}{ }^{++}, 0.8 \mathrm{mM} \mathrm{Mg}^{++}\right.$) with ${ }^{45} \mathrm{Ca}^{++}(0.5 \mu \mathrm{Ci} / \mathrm{ml})$ added and in the presence of carbachol $(100 \mu \mathrm{M})$ where indicated. Cell suspensions were pelleted through a $12 \%$ BSA solution containing $5 \mathrm{mM}$ EDTA. Centrifuging the cells through EDTA reduced the ${ }^{45} \mathrm{Ca}^{++}$accumulated at $15 \mathrm{~min}$ from $1.26 \pm 0.26$ to $0.55 \pm 0.04$ $\mathrm{nmol} / 10^{6}$ cells for untreated cells and from $1.91 \pm 0.31$ to $1.13 \pm 0.17 \mathrm{nmol} / 10^{6}$ cells for cells treated with $100 \mu \mathrm{M}$ carbachol. Data are the mean $\pm \mathrm{SE}$ from six preparations.

sumption ( $r=0.93$, Fig. 8), and on AP accumulation ( $r=0.90$, data not illustrated). In contrast to these effects of carbachol, neither histamine nor gastrin increased calcium uptake (Fig. 6B). The addition of histamine to carbachol did not significantly increase ${ }^{45} \mathrm{Ca}^{++}$uptake above that found with carbachol alone (Fig. 9). The combination of histamine and gastrin did not alter ${ }^{45} \mathrm{Ca}^{++}$uptake above that found with untreated cells (Fig. 9). Furthermore, the combination of the phosphodiesterase inhibitor isobutylmethylxanthine and $10 \mu \mathrm{M}$ histamine did not alter the rate of ${ }^{45} \mathrm{Ca}^{++}$uptake found with untreated cells $(P>0.2$, $n=3$ for 3,5 , and $10 \mathrm{~min}$ of incubation).

The above studies were done with fractions enriched to a parietal cell content of $\sim 50 \%$. To establish that parietal cells accounted for the enhanced ${ }^{45} \mathrm{Ca}^{++}$ uptake found with stimulation by carbachol, fractions of variable parietal cell content obtained with the elutriator rotor were examined. Carbachol failed to stimulate ${ }^{45} \mathrm{Ca}^{++}$uptake in the parietal cell-depleted fractions, and in the remaining fractions the magnitude of the carbachol-stimulated uptake correlated with the parietal cell content $(r=0.88$, Fig. 10).

The effects of stimulants on mobilization of intracellular calcium. Evidence that gastric secretagogues activate parietal cell function by mobilizing intracellular calcium was sought by studying calcium egress from cells previously incubated in ${ }^{45} \mathrm{Ca}^{++}$containing medium. Several experimental protocols were used. When cells were incubated in a ${ }^{45} \mathrm{Ca}^{++}$-containing medium for $1 \mathrm{~h}$ and then treated with gastrin $(100 \mathrm{nM})$, histamine $(10 \mu \mathrm{M})$, or carbachol $(100 \mu \mathrm{M})$, no statistically 


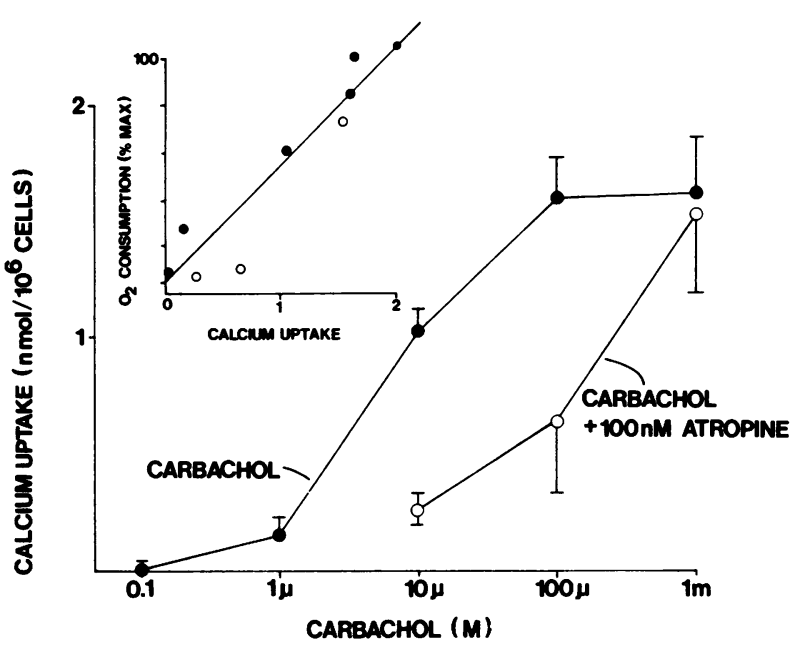

Figure 8 Dose-response relationship for carbachol stimulation of ${ }^{45} \mathrm{Ca}^{++}$uptake. The data are the mean from three preparations of cells incubated in Earles' salts $\left(1.8 \mathrm{mM} \mathrm{Ca}^{++}\right.$, $0.8 \mathrm{mM} \mathrm{Mg}^{++}$) for $10 \mathrm{~min}$, with $0.5 \mu \mathrm{Ci} / \mathrm{ml}^{45} \mathrm{Ca}^{++}$then added along with the indicated concentrations of carbachol and $100 \mathrm{nM}$ atropine as noted. ${ }^{45} \mathrm{Ca}^{++}$accumulation was measured after an additional $10 \mathrm{~min}$ and expressed in $\mathrm{nmol} / 10^{6}$ cells, with basal calcium uptake subtracted. (Insert) Data for stimulation of oxygen consumption (Fig. 6, ref. 13) by carbachol (closed circles) and carbachol plus $100 \mathrm{nM}$ atropine (open circles) have been plotted as a function of the effects of these same treatment groups on calcium uptake. The line was drawn by linear regression analysis; the correlation coefficient for the relationship was $0.93(P<0.01)$.

significant alterations in the cellular content of radioactivity were detected, although there was a trend suggesting an increased cellular content of ${ }^{45} \mathrm{Ca}^{++}$during

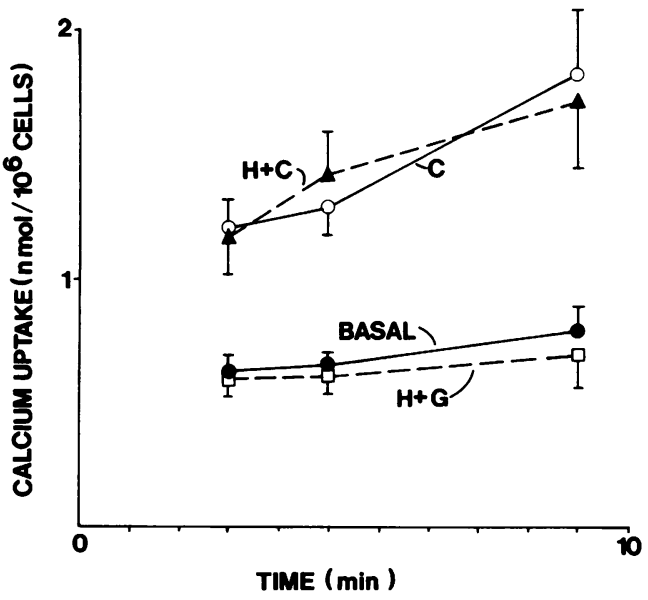

Figure 9 The effects of combinations of agents on ${ }^{45} \mathrm{Ca}^{++}$ uptake. ${ }^{45} \mathrm{Ca}^{++}$uptake was determined for seven preparations of cells in the presence of histamine $(10 \mu \mathrm{M})$, histamine plus gastrin (100 nM), histamine plus carbachol $(100 \mu \mathrm{M})$, and carbachol alone. Cells were incubated in Earles' salts (1.8 $\mathrm{mM} \mathrm{Ca}{ }^{++}, 0.8 \mathrm{mM} \mathrm{Mg}{ }^{++}$) with $0.5 \mu \mathrm{Ci} / \mathrm{ml}^{45} \mathrm{Ca}$ added.

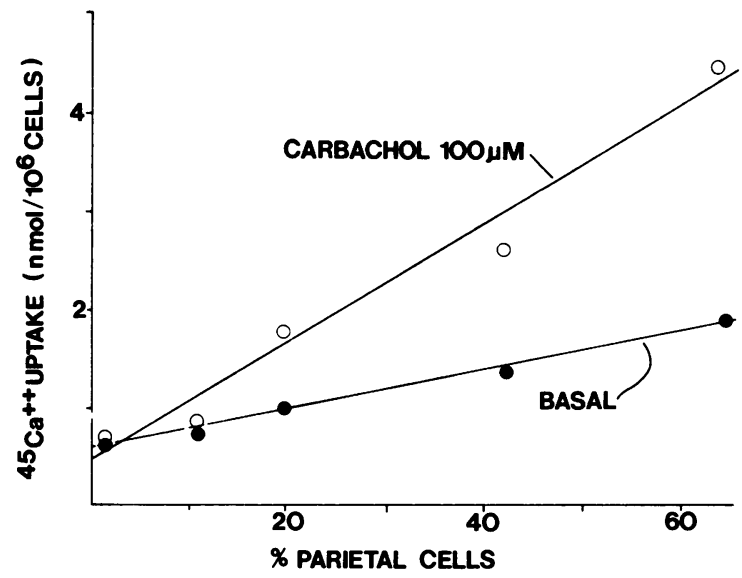

Figure 10 Carbachol stimulation of ${ }^{45} \mathrm{Ca}^{++}$uptake in fractions of varying parietal cell content. Cell separation was accomplished using the elutriator rotor as previously described $(13,17)$. Cells were incubated for $10 \mathrm{~min}$ in Earles' medium (1.8 $\mathrm{mM} \mathrm{Ca}^{++}, 0.8 \mathrm{mM} \mathrm{Mg}^{++}$), with $0.5 \mu \mathrm{Ci}$ of ${ }^{45} \mathrm{Ca}^{++}$then added and uptake was determined after an additional 10-min incubation and expressed in nanomoles per $10^{6}$ cells. Parietal cell contents of the various fractions was determined by counting hematoxylin and eosin stained slides prepared using a Shandon cytocentrifuge. The lines drawn were based upon linear regression analyses. The correlation coefficient for the relationship between the increment over basal calcium uptake produced by carbachol treatment and the parietal cell contents was 0.98 for the single cell preparation that is illustrated. Similar cell separation experiments were done using three other cell preparations $(0.98,0.86$, and 0.83$)$; the correlation coefficient obtained by Fisher " $\mathrm{z}$ " transformation for the relationship between the increment over basal calcium uptake produced by carbachol and the parietal cell content was $0.88(P<0.05)$. Pepsinogen contents were also determined in three of these cell separation experiments, being measured as previously described (17). No correlation was found between the pepsinogen contents and the carbacholstimulated increment in calcium uptake $(r=0.62, P>0.2)$.

carbachol treatment $(n=4, P>0.1$, data not illustrated). Centrifuging the cells through EDTA to remove rapidly exchangeable ${ }^{45} \mathrm{Ca}^{++}$did not alter these latter findings. After preloading cells with ${ }^{45} \mathrm{Ca}^{++}$in a similar fashion, the addition of $5 \mathrm{mM}$ EDTA to the incubation medium produced a rapid fall in cellular calcium, the rate of which was not altered by treatment with the same stimulants $(n=5, P>0.1$, data not illustrated). Cells preloaded with ${ }^{45} \mathrm{Ca}^{++}$and then rapidly centrifuged twice to remove extracellular ${ }^{45} \mathrm{Ca}^{++}$lost their cellular radioactivity in a time-dependent fashion, but this rate of calcium egress was not accelerated by treatment with stimulants (Fig. 11).

\section{DISCUSSION}

The effect of histamine, carbachol, and gastrin on parietal cell function were each dependent to some degree upon the concentration of extracellular calcium. 


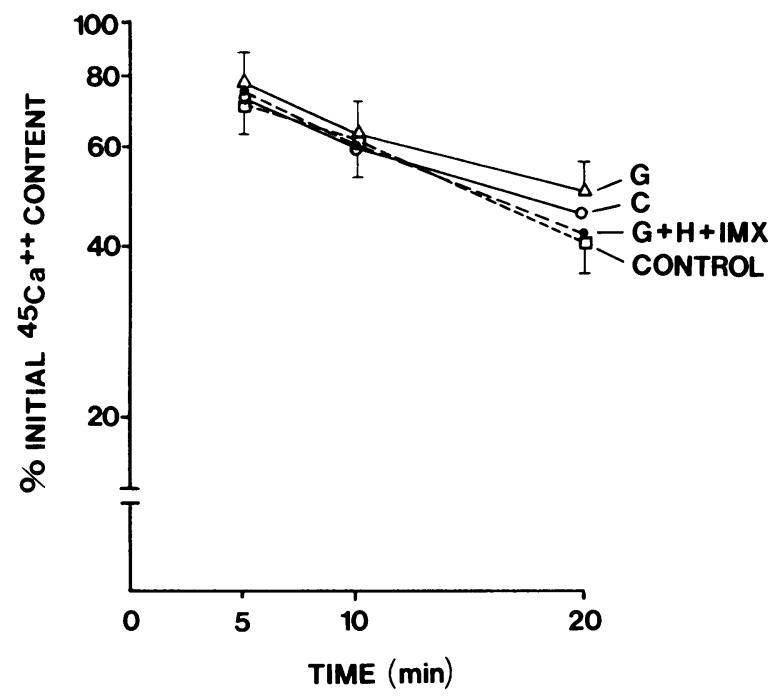

Figure $11{ }^{45} \mathrm{Ca}^{++}$outflux from preloaded cells. Parietal cell enriched fractions from seven preparations were incubated for $1 \mathrm{~h}$ in minimum essential medium $\left(0.3 \mathrm{mM} \mathrm{Ca}^{++}, 0.8 \mathrm{mM}\right.$ $\mathrm{Mg}^{++}$) in the presence of $1.0 \mu \mathrm{Ci} / \mathrm{ml}$ of ${ }^{45} \mathrm{Ca}^{++}$. Cells were centrifuged twice $(200 \mathrm{~g}, 2 \mathrm{~min})$, and resuspended in fresh Earles' balanced salt solution (1.8 $\mathrm{mM} \mathrm{Ca}, 0.8 \mathrm{mM} \mathrm{Mg}^{++}$). The initial ${ }^{45} \mathrm{Ca}^{++}$content of cells was determined for each group and then the cells were treated as indicated with gastrin $(100 \mathrm{nM})$, carbachol $(100 \mu \mathrm{M})$, or gastrin $(100 \mathrm{nM})$ plus histamine $(10 \mu \mathrm{M})$ and isobutylmethylxanthine $(100 \mu \mathrm{M})$. ${ }^{45} \mathrm{Ca}^{++}$content was determined at the indicated times and expressed as a percentage of the initial cell content, which was found to be $2,460 \pm 650 \mathrm{cpm} /$ pellet. To determine whether carbachol enhanced ${ }^{45} \mathrm{Ca}^{++}$uptake into cells treated in this fashion, in three of these preparations an additional set of cells were incubated under similar conditions but with ${ }^{45} \mathrm{Ca}^{++}$ only added after $60 \mathrm{~min}$. After an additional $10 \mathrm{~min}$ of incubation, the ${ }^{45} \mathrm{Ca}^{++}$content of untreated cells was $1.17 \pm 0.14$ and $2.32 \pm 0.35 \mathrm{nmol} / 10^{6}$ cells in cells treated with $100 \mu \mathrm{M}$ carbachol.

However, carbachol-stimulated AP accumulation was markedly impaired with reduction of the calcium concentration from 1.8 to $0.1 \mathrm{mM}$, while only modest impairment of histamine-stimulated parietal cell function occurred with this reduction. This degree of calcium removal produced an intermediate impairment of the small response to gastrin. The decrease in parietal cell responsiveness to cholinergic stimulation found under these conditions was reversed completely by restoration of the calcium concentration to normal. This recovery of cholinergic responsiveness was rapid; the time-course for carbachol stimulation of AP accumulation in the period immediately following restoration of the calcium concentration was not different from that found for cells that had remained in normal calcium.

Studies with lanthanum provided further evidence for the above pattern of dependency of secretagogue action upon extracellular calcium. Treatment of parietal cells with lanthanum caused marked suppression of the response to carbachol, intermediate impairment of the response to gastrin, and no alteration of histamine-stimulated parietal cell function. Lanthanum does not permeate plasma membranes of intact cells, and therefore probably acts at surface sites to block calcium movement across the plasma membrane (10). The present data therefore indicate that cholinergic stimulation requires the presence of a rapidly exchangeable calcium pool at a lanthanum-accessible site, presumably on the membrane of the parietal cell.

In several cell types, including heart muscle (5), chromaffin cells from the adrenal medulla (7), mast cells (9), and beta cells from the pancreatic islets (8), cell activation by certain chemical transmitters requires the presence of extracellular calcium and is associated with an enhanced influx of calcium upon activation $(2-4,11,19)$. The possibility that activation of parietal cell function involved enhanced calcium influx, or calcium gating, was evaluated using ${ }^{45} \mathrm{Ca}^{++}$. Carbachol, but not gastrin or histamine, enhanced calcium uptake during the $30 \mathrm{~min}$ following treatment. This cholinergic effect on calcium uptake occurred over a similiar time period in which stimulation of AP accumulation was found. Furthermore, the dose response for cholinergic stimulation of calcium uptake correlated with effects on oxygen consumption and AP accumulation. Atropine in low concentrations produced surmountable, rightward displacement of the carbachol dose-response relationship, consistent with specific action at a muscarinic receptor. In cell separation experiments, the magnitude of the carbachol-stimulated calcium uptake was proportional to the parietal cell content, but not the pepsinogen content, of the various fractions, thus indicating that parietal cells accounted for the observed changes in calcium uptake with stimulation. These data do not exclude changes in calcium uptake occurring with cholinergic stimulation in other cell types; the present techniques simply do not detect such changes. The findings of an accelerated rate of calcium uptake 1 min following treatment with carbachol, at a time when the cellular content of ${ }^{45} \mathrm{Ca}^{++}$was low, and the failure to find an alteration in calcium egress from cells preloaded with ${ }^{45} \mathrm{Ca}^{++}$(vide infra) support the view that cholinergic agents, but not histamine or gastrin, enhance calcium influx into parietal cells. This conclusion does not account for the finding that histamine stimulation of AP accumulation was impaired with removal of extracellular calcium. However, this impairment was only minimal, and histamine stimulation was neither blocked by lanthanum nor associated with enhanced uptake or egress of calcium across the plasma membrane. The minimal dependency of histamine action upon extracellular calcium evident in the present studies may reflect diminution of intracellular 
calcium pools with calcium removal, with subsequent impairment of a calcium-dependent, rate-limiting step(s) in the parietal cell response to histamine.

Histamine and cholinergic agents trigger cell activation by distinct effector mechanisms, with histamine action linked to enhanced production of cyclic AMP (15) and cholinergic stimulation associated with enhanced calcium uptake. In contrast, gastrin action is clearly linked neither to enhanced cyclic AMP production (15) nor enhanced calcium uptake, although the moderate dependency of gastrin action upon extracellular calcium and impairment by lanthanum suggest a role for calcium in gastrin activation of cell function. It is possible that the failure to find gastrin effects on calcium uptake or cyclic AMP production may reflect a somewhat impaired response of canine parietal cells isolated by the present techniques to gastrin stimulation $(13,14)$. Alternatively, gastrin may act by yet another mechanism, such as mobilization of calcium from intracellular stores. In cell types, such as those from skeletal muscle (5), pancreatic acinae $(12,20)$, renal tubules $(6)$, and insect salivary glands (21), activation by stimulants has been linked to release of calcium from intracellular binding sites. In these instances, cell activation does not show the same degree of immediate dependency upon changes in extracellular calcium concentration, although depletion of cellular calcium can impair responsiveness $(12,22)$. In the present study no evidence was found to link histamine, carbachol, or gastrin activation of cell function to enhanced egress of intracellular calcium. Even though these cell preparations responded to stimulation as evidenced by enhanced aminopyrine accumulation, negative data with isolated cells require cautious interpretation; the role of intracellular calcium in the activation of parietal cell function requires further study. Furthermore, with this preparation of cells, enhanced calcium uptake was detected when ${ }^{45} \mathrm{Ca}^{++}$ and carbachol were added simultaneously, but only a trend suggesting increased uptake was found when carbachol was added $1 \mathrm{~h}$ after the ${ }^{45} \mathrm{Ca}^{++}$. Whether this apparent discrepancy and the failure of cellular ${ }^{45} \mathrm{Ca}^{++}$accumulation to reach a steady state in a $3-\mathrm{h}$ period reflect impaired cell function and viability after more prolonged incubation or reflect some other factor remains to be determined.

The role of calcium in the regulation of acid secretion in vivo has not been fully clarified. Calcium by intravenous infusion stimulates acid secretion $(23,24)$, an effect antagonized by magnesium $(23,25)$. This in vivo effect of calcium may be directly on oxyntic tissue in that antrectomy fails to abolish it (24), although this point in controversal (26). These observations are consistent with the present findings with isolated parietal cells that calcium enhanced basal AP accumulation and that this effect was antagonized by magnesium. The role of calcium in secretagogue action in vivo is difficult to study, since one cannot selectively remove the calcium pool available to the parietal cell. Infusion of EDTA reduces the response to all stimulants, an effect which is difficult to interpret (27). Intravenous infusions of calcium enhances the response to pentagastrin and to cholinergic stimulation $(25,27)$, but these observations may be explained by mechanisms other than calcium involvement in parietal cell activation by secretagogues.

Potentiating interactions have been found between histamine and both gastrin and cholinomimetic agents, but not directly between gastrin and carbachol in their actions on the function of isolated canine parietal cells $(28,29)$. The existence of these potentiating interactions may explain the interdependency between secretagogues in their action on acid secretion in vivo (28). With isolated canine parietal cells, potentiating interactions occur with the combination of a cyclic AMP-dependent effector mechanism (histamine) and a calcium-dependent effector mechanism (carbachol and possibly gastrin), as was noted for pancreatic acinar cells (30). The mechanisms underlying these potentiating interactions are not known, and the data available at present only serve to exclude a few possibilities. Adding gastrin or carbachol to histamine did not alter the magnitude of histamine-stimulated cyclic AMP production (15), and adding histamine to carbachol failed to amplify cholinergic-stimulated calcium influx (present data), with these findings indicating that amplification occurs at a step after initial cell activation. New approaches will be necessary to elucidate the mechanisms underlying the potentiating interactions between secretagogues that appear to be a major regulating factor in parietal cell function in vivo.

\section{ACKNOWLEDGMENTS}

The author is deeply indebted to Dr. Glenn Langer for his suggestions and criticisms regarding these studies and to Dr. Morton I. Grossman for his advice and support of this work. The author is also indebted to Debbie Amirian, June Ferrari, Tammie White, Janis Kurihara, and Aija Fox for their invaluable technical assistance at various stages of this work; to Michele Hamilton for her input during a summer student fellowship; and to Anita Boesman for secretarial assistance.

This project was supported in part by the grant to the Center for Ulcer Research and Education (AM 17328) and grant AM 19984, both from the National Institute of Arthritis, Metabolism, and Digestive Diseases, and by the Medical Research Service of the Veterans Administration.

\section{REFERENCES}

1. Soll, A. H. 1979. The dependence of carbachol stimulation of ${ }^{14} \mathrm{C}$-aminopyrine accumulation of isolated canine parietal cells upon extracellular calcium. Gastroenterology. 76: 1251. (Abstr.) 
2. Berridge, M. J. 1975. The interaction of cyclic nucleotides and calcium in the control of cellular activity. In Advances in Cyclic Nucleotide Research. P. Greengard and G. A. Robison, editors. Raven Press, New York. 6: 1-98.

3. Douglas, W. W. 1976. The role of calcium in stimulussecretion coupling. In Stimulus-Secretion Coupling in the gastrointestinal Tract. R. M. Case and H. Goebell, editors. M.T.P. Press Ltd., Lancaster, England. 17-29.

4. Rasmussen, H., and D. B. P. Goodman. 1977. Relationships between calcium and cyclic nucleotides in cell activation. Physiol. Rev. 57: 421-509.

5. Langer, G. A. 1976. Events at the cardiac sarcolemma: localization and movement of contractile-dependent calcium. Fed. Proc. 35: 1274-1278.

6. Borle, A. B. 1973. Calcium metabolism at the cellular level. Fed. Proc. 32: 1944-1950.

7. Douglas, W. W. 1968. Stimulus-secretion coupling: the concept and clues from chromaffin and other cells. (The first Gaddum Memorial Lecture). Br. J. Pharmacol. 34: 451-474.

8. Curry, D. L., L. L. Bennett, and G. M. Grodsky. 1968. Requirement for calcium ion in insulin secretion by the perfused rat pancreas. Am. J. Physiol. 214: 174-178.

9. Foreman, J. C., and J. L. Mongar. 1972. The role of alkaline earth ions in anaphlactic histamine secretion. J. Physiol. (Lond.). 224: 753-769.

10. Langer, G. A., and J. S. Frank. 1972. Lanthanum in heart cell culture: effect on calcium exchange correlated with its localization. J. Cell Biol. 54: 441-455.

11. Douglas, W. W., and A. M. Poisner. 1962. On the mode of action of acetylcholine in evoking adrenal medullary secretion: increased uptake of calcium during the secretory response. J. Physiol. (Lond.). 162: 385-392.

12. Williams, J. A. 1980. Regulation of pancreatic acinar cell function by intracellular calcium. Am. J. Physiol. 238: G269-G279.

13. Soll, A. H. 1978. The actions of secretagogues on oxygen uptake by isolated mammalian parietal cells. J. Clin. Invest. 61: 370-380.

14. Soll, A. H. 1980. Secretagogue stimulation of ${ }^{14} \mathrm{C}$-aminopyrine accumulation by isolated canine parietal cells. Am. J. Physiol. 238: G366-G375.

15. Soll, A. H., and A. Wollin. 1979. Histamine and cyclic AMP in isolated canine parietal cells. Am. J. Physiol. 237: E444-E450.

16. Berglindh, T., D. R. Dibona, S. Ito, and G. Sachs. 1980. Probes of parietal cell function. Am. J. Physiol. 1: G165G176.
17. Wollin, A., A. H. Soll, and I. M. Samloff. 1979. Actions of histamine, secretin, and $\mathrm{PGE}_{2}$ on cyclic AMP production by isolated canine fundic mucosal cells. Am. J. Physiol. 237: E437-E443.

18. Snedecor, G. W., and W. G. Cochran. 1967. Statistical Methods. Iowa State University Press, Ames, Iowa. 185188.

19. Malaisse-Lagae, F., and W. J. Malaisse. 1971. Stimulussecretion coupling of glucose-induced insulin release. III. Uptake of ${ }^{45}$ calcium by isolated islets of langerhans. Endocrinology. 88: 72-80.

20. Gardner, J. D., T. P. Conlon, H. L. Klaeveman, T. D. Adams, and M. A. Ondetti. 1975. Action of cholecystokinin and cholinergic agents on calcium transport in isolated pancreatic acinar cells. J. Clin. Invest. 56: 366-375.

21. Prince, W. T., M. J. Berridge, and H. Rasmussen. 1972. Role of calcium and adenosine-3',5'-cyclic monophostate in controlling fly salivary gland secretion. Proc. Natl. Acad. Sci. U. S. A. 69: 553-557.

22. Chandler, D. E. 1978. Control of pancreatic enzyme secretion: a critique of the role of calcium. Life Sci. 23: 323-324.

23. Hotz, J., H. Goebell, and R. Ziegler. 1976. The role of calcium in gastric acid and pepsin secretion. In Stimulussecretion Coupling in the Gastrointestinal Tract. R. M. Case and H. Goebell, editors. M. T. P. Press, Ltd., Lancaster, England. 159-172.

24. Basso, N., and E. Passaro, Jr. 1970. Calcium-stimulated gastric secretion in the Zollinger-Ellison syndrome. Arch. Surg. 101: 399-402.

25. Christiansen, J., J. F. Rehfeld, and P. Kirkegaard. 1979. Interaction of calcium, magnesium, and gastrin on gastric acid secretion. Gastroenterology. 76: 57-61.

26. Christiansen, J., J. F. Rehfeld, and F. Stadil. 1974. The effect of calcium on gastric acid and gastrin secretion in antrectomized subjects. Gut. 15: 622-625.

27. Basso, N., and E. Passaro, Jr. 1972. Effect of calcium on pentagastrin-, histamine-, bethanecol-, and insulin-, stimulated gastric secretion in the ferret.J. Surg. Res. 13: 32-38.

28. Soll, A. H. 1978. The interaction of histamine with gastrin and carbamylcholine on oxygen uptake by isolated mammalian parietal cells. J. Clin. Invest. 61: 381-389.

29. Soll, A. H. 1978. Three-way interactions between histamine, carbachol, and gastrin on aminopyrine uptake by isolated canine parietal cells. Gastroenterology. 74: 1146. (Abstr.)

30. Gardner, J. D., and M. J. Jackson. 1977. Regulation of amylase release from pancreatic acinar cells. J. Physiol. (Lond.). 270: 439-444. 